\title{
Insist on Discourse Right of Ideological Work in Colleges and Universities in the New Media Era Xinying $\mathrm{Lu}{ }^{1}$, a, Jing Huang ${ }^{2}$, \\ ${ }^{1}$ Marx School of Xi'an University of Science and Technology 710054, China; \\ 2 Marx School of Xi'an University of Science and Technology 710054, China. a 476158259@qq.com, b 287394026@qq.com
}

Keywords: new media, colleges and universities, ideology, discourse right.

\begin{abstract}
The rise of new science and technology revolution in the latter half of the twentieth Century is pushing human society towards a new information era -- an era of new media. As an important carrier of ideology and a new platform, the new media has an important influence on the development of ideology. Ideology is an important ideological foundation of social and national stability, and ideological work is an extremely important work of the party. As the frontier of ideological work, it is necessary to improve the system of ideological work in Colleges and universities, and to grasp the discourse right.
\end{abstract}

\section{Introduction}

With the rapid development of new media, the influence of network on ideology so far exceeds that of any traditional media, the rapid development of new media technology triggered the information revolution, which has brought a severe impact on dominant position of the socialist ideology, the discourse right of socialist ideology is facing serious challenges. As the frontier of ideology, colleges and universities shoulder the arduous task of maintaining and developing the mainstream ideology of socialism and fighting against the deliberate destruction of ideology in our country. Therefore, in the new media era, it has great theoretical and practical importance to explore how colleges and universities to use their own advantages, to improve the ideological and political work of universities in discourse system.

\section{New Media Made an Impact on Youth's Ideology}

With the rapid development of network technology and digital technology, as the main media of the generation and dissemination of public opinion, new media has been the main channel for the majority of young people to obtain information, but the dissemination of information of uneven quality brings impact on the formation of youths' Ideology. Colleges and universities are the frontiers in the field of ideology education, and important bases to train builders and successors of socialism with Chinese characteristics. We must firmly establish the discourse right of ideological work and pay close attention to the ideological education of young people.

\section{The concept and characteristics of the new media}

It is generally believed that the "new media " refers to media forms emerged under the new technical support system which appears after newspaper, radio and television stations, including: Internet, Internet radio, Internet TV, etc.. The development of new media is a double-edged sword. Compared with the traditional media, the new media has the characteristics of rich in content, openness and interaction in dissemination, and lagging in related management. These characteristics have formed a challenge to the ideology of college students. New media is an open world, people will not be restricted by time, space 
and national ideology to a certain extent. This makes the the western developed countries with the advantage of its information technology, penetrating ideology in our country through the Internet, film and television literature and other forms, bringing a strong impact on the dominant position of socialist ideology in our country.

\section{New media provides a new platform for ideological work in Colleges and universities.}

Colleges and universities represent the direction of cultural progress of the state and society, and play a guiding role in the formation of young people's thoughts and values, and provides a better platform for the ruling party to grasp the active power of ideology. The effect of ideological control in Colleges and universities will directly affect the effectiveness of ideological control in the whole society. The network characteristics of new media , as well as its global, social, subjective and interactive nature of the communication and the mode of transmission provide a new platform for the ideological work of colleges and universities. For college students who are frontiers of the community, they pay attention to the role of new technology, and accept new things easily, therefore, they are more willing to accept the transmission of the ideological mode with new media. While attaching importance to the traditional media, colleges and universities should make full use of new media to build a learning and communication platform. The website of theory learning and thought and political theory course, campus BBS can become platforms for the construction of the socialist core value system, to create a network environment and atmosphere 【 1 】 for college students' acceptance and practice of socialist core value system. It is a new platform for the ideological work of colleges and universities to spread the mainstream ideology of our country with a way which can be accepted willingly.

\section{The impact of new media on the ideological work of colleges and Universities}

In the era of new media, the openness of the network information has reconstructed the cultural environment of the socialist ideology. The impact of new media on college students' the formation and development of outlook of life, world and values, as well as their way of thinking and behavior is comprehensive and profound. In the new media environment, college students not only receive information passively through the network, but also take the initiative to create information and send information. However, college students' ideology is not yet fully mature, leading to the lack of discrimination ability of information and speech on the Internet 【 2 】. In the new media era, dissemination way of information on the Internet has weakened the university students' ideological control power.

\section{The influence of the ideological and political education mode in Colleges and Universities}

With the continuous development of Internet technology in our country, informatization level of our country has been promoted accordingly, the new media therewith has brought new opportunities for the development of Ideological and political work in colleges and universities in China at present, but the traditional ideological and political teaching mode also highlights its shortcomings in the process of reform in colleges and universities. Traditional mode of ideological and political teaching generally adopts the way of transfer----accept. Teachers usually teach according to the teaching plan designed in advance with less interaction between teachers and students, resulting in the ignorance of students' initiative and creativity. This leads to the reality that students do not want to ask and do not think about 'why', students have a smattering of knowledge on many issues, adopt a poor method of learning by rote in order to pass examinations, and form a blind worship of books and teachers. The traditional mode of Ideological and political education makes the students' 
divergent thinking and reverse thinking be bound and imprisoned. While network, as the main carrier of information and communication at present, becomes an increasingly important channel for college students to acquire knowledge and information. Featuring wide coverage, real-time information and lasting effect, network information can provide students with fast and abundant information and plenty knowledge. This reduces the effect of traditional ideological and political education teaching greatly. Whether the richness of classroom knowledge or the speed of obtaining the latest knowledge, traditional ideological and political teaching mode can not compare with the browse on the Internet by students themselves, which makes students have a strong doubt on the content taught by traditional ideological and political education teaching mode. The authority of the traditional ideological and political education has been impacted and challenged.

\section{The impact on the formation of college students' outlook of world, life and values}

The new media is getting more and more attention and dependence of college students, and has become an important way to obtain and exchange information. And it is well known that college students is in the critical period of psychological and physiological development, the continuous innovation and the rich content of network media have a profound impact on the formation of students' outlook of world, life and values. The college students growing up in the new media environment can access to various information more conveniently. With the help of network, college students can not only know more political information which enables enhances the students' awareness of political participation and democratic consciousness, also access to positive attitude which improves the college students' critical spirit and moral cultivation. However, the network information is also uneven in quality which may make students question the mainstream ideology. For example, after reading some reports, college students with less legal knowledge can not judge the truth calmly and rationally, causing negative emotional reflection only from the surface of negative information, considering individual case as the situation of the whole society, thus corroding college students' socialist legal concept 【3】. There is no doubt that the money worship, hedonism and showing off the wealth which is popular on the Internet, will have a certain negative impact on college students' outlook of life, world and values.

\section{Specific measures of adhering to the ideological discourse right for colleges and universities}

The effectiveness of ideological work in Colleges and universities not only affects the development and stability of colleges and universities themselves, and the society, the most important is that it has impact on the safety of the regime. In order to do a good job in the publicity and ideological work under the new situation, we must grasp the leadership and discourse right the ideological work firmly. We must establish a strong ideological indoctrination and occupation consciousness in ideological and political education of college students, take the initiative to occupy the ideological position of colleges and universities with advanced ideology and culture, instill the socialist core value system into college students, arm college students with the theory of socialism with Chinese characteristics, grasp the discourse right, the initiative and the dominant power in the field of Ideological and political education of college students firmly.

\section{The reform of teaching mode of Ideological and Political Education}

With the changing of science and technology, the new media brings opportunities and challenges to the ideological and political education. As the frontier of ideological and political education, colleges and universities must grasp the opportunities for ideological and 
political education brought by new media, implement network teaching using modern information technology timely, establish ideological and political education website, making network an an important platform and means to carry forward the main melody of the ideological and political. The purpose of education and teaching of the ideological and political theory course in Colleges and universities is to cultivate the advanced specialized talents with innovative spirit, which surely requires the teachers to have the spirit of innovation, which features no blind obedience, no conservation, be keen on reformation, be courageous to forge ahead, and be good at discovering, protecting and cultivating the innovation spirit of students'. This requires teachers who has rich theoretical knowledge and teaching experience to follow the pace of the times and to communicate with and teach students effectively using network technology platform. The richness of new media resources requires that colleges and universities have rich network learning resources, while the abundance of teaching resources should be based on the needs of students, strengthen the correct guidance for college students' ideological orientation, create a good teaching environment and network platform, offer mental health services to college students from theory to practice, so as to enhance the effectiveness of Ideological and Political Education.

\section{The reform of teaching mode of Ideological and Political Education}

With the changing of science and technology, the new media brings opportunities and challenges to the ideological and political education. As the frontier of ideological and political education, colleges and universities must grasp the opportunities for ideological and political education brought by new media, implement network teaching using modern information technology timely, establish ideological and political education website, making network an an important platform and means to carry forward the main melody of the ideological and political. The purpose of education and teaching of the ideological and political theory course in Colleges and universities is to cultivate the advanced specialized talents with innovative spirit, which surely requires the teachers to have the spirit of innovation, which features no blind obedience, no conservation, be keen on reformation, be courageous to forge ahead, and be good at discovering, protecting and cultivating the innovation spirit of students'. This requires teachers who has rich theoretical knowledge and teaching experience to follow the pace of the times and to communicate with and teach students effectively using network technology platform. The richness of new media resources requires that colleges and universities have rich network learning resources, while the abundance of teaching resources should be based on the needs of students, strengthen the correct guidance for college students' ideological orientation, create a good teaching environment and network platform, offer mental health services to college students from theory to practice, so as to enhance the effectiveness of Ideological and Political Education.

\section{References}

[1] Wang Jia, Dai Yanjun. Ed.2012. Theory and Practice of Socialist Core Value System Education in Colleges and Universities.

[2] Wei Xiaowen, Shao Fangqiang. Ed.2014. On the Construction of University Ideological Security under Network Background[J]. Research on Ideological Education.

[3] He Lingxian. Ed.2013. Research on the Influence of Network Popular Words on College Students' Values[D]. Chongqing: Chongqing Technology and Business University.

[4] Qiao Wanmin, Xing Liang. Ed.2013. Study on the Improvement Mode of College and University Students' Ideological and Political Education Quality[M]. People's Publishing House.

[5] Luo Yuting. Ed.2011. The Development and Innovation of Campus Network Culture[J]. Research on Ideological and Political Education. 